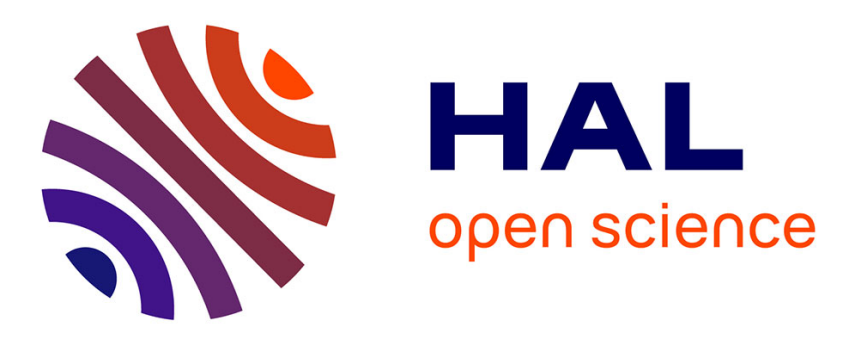

\title{
Making Sense or/of Decisions? Collective Action in Early Release Process
}

Joséphine Bastard, Christophe Dubois

\section{To cite this version:}

Joséphine Bastard, Christophe Dubois. Making Sense or/of Decisions? Collective Action in Early Release Process. Modernisation of the Criminal Justice Chain and the Judicial System New Insights on Trust, Cooperation and Human Capital, 50, Springer, pp.159-172, 2015, 978-3-319-25800-3. 10.1007/978-3-319-25802-7_11. hal-02541731

\section{HAL Id: hal-02541731 \\ https://hal.science/hal-02541731}

Submitted on 14 Apr 2020

HAL is a multi-disciplinary open access archive for the deposit and dissemination of scientific research documents, whether they are published or not. The documents may come from teaching and research institutions in France or abroad, or from public or private research centers.
L'archive ouverte pluridisciplinaire HAL, est destinée au dépôt et à la diffusion de documents scientifiques de niveau recherche, publiés ou non, émanant des établissements d'enseignement et de recherche français ou étrangers, des laboratoires publics ou privés. 


\title{
Making Sense or/of Decisions? Collective Action in Early Release Process
}

\author{
Joséphine Bastard 1,* \\ Email josephine.bastard@ulg.ac.be \\ Christophe Dubois 1 \\ Email c.dubois@ulg.ac.be
}

${ }^{1}$ CRIS, University of Liège, Liège, Belgium

\section{Abstract}

The abstract is published online only. If you did not include a short abstract for the online version when you submitted the manuscript, the first paragraph or the first 10 lines of the chapter will be displayed here. If possible, please provide us with an informative abstract.

The Belgian Sentence Implementation Court is responsible for the decision of early release from prison. Different professional groups are involved in the making of such a decision: judges, prison governors, prison clerks, psychosocial teams and the prison central administration. Describing the legal framework as well as the practices and interactions through which the stakeholders enact the 2006 Act, this chapter underlines the role of documents and "sensemaking" (Weick et al. Organizing and the process of sensemaking. Organ Sci 16(4):409-421, 2005) in the collective decision-making process. Making sense of various documents (the judgement and description of the offence by the public prosecutor, reports, recommendations, requests, hearing convocations, etc.), the stakeholders are progressively framing the decision of the court.

\section{AQ1}

\subsection{Introduction}

In Belgium, since the 1st of February 2007, Sentence Implementation Courts (SIC) have been responsible for granting early release to prisoners serving a sentence of more than three years. Far from the traditional idea of a ritualised justice (Garapon 2001), this court "does not judge" but makes decisions. These decisions are not produced through the syllogistic reasoning of some judges mechanically applying general rules to specific cases (Beccaria 2006). They rather depend on complex organising processes, enacted by various professional groups: SIC magistrates, prison governors, prison clerks, Prison Psychosocial Team (PST), and Prison Central Administration (Halliday et al. 2009). Those professionals are producing and making sense of diverse documents (Freeman 2006).

This chapter looks at the process through which judicial decisions are made by the SIC. It aims at accounting for the cooperation between the stakeholders. The formal coordination between the professional groups will be depicted, as well as their concrete practices and interactions. In doing so, we will emphasise the importance of documents as "boundary objects" (Star and Griesemer 1989) supporting professionals' 
cooperation. We will also analyse how "sensemaking” (Weick et al. 2005) underlies collective action across time and space along the sentence enforcement process.

\subsubsection{Theoretical Framework}

Our main assumption is that the court's decisions are coproduced by professional groups involved in the early release process, rather than automatically produced by the mechanical application of the 2006 Act. Cooperation and "sensemaking" will be our main analytical concepts. Sociological definitions of cooperation usually highlight the ideas of collective action, interdependent relationships, and reciprocal adjustments. Following Friedberg (1997: 3), we will study the "processes of organisation that shape, stabilise, and coordinate the behaviour and strategic interactions of a certain number of actors whose interdependence makes cooperation indispensable, but who all preserve some degree of autonomy and continue, for many reasons, to pursue divergent interests".

Cooperation along the sentence execution chain is made necessary by the rules and the procedure, requiring interdependent relationships between various groups of actors. In order to account for the process through which these rules are concretely enacted, we will firstly focus on the documents that are produced, processed, (re)interpreted, and then transmitted. Whatever their nature (evidence, written recommendation, or record), these documents are useful tools for describing collective action processes. Secondly, the concept of "sensemaking" will help us in analysing the incremental decision-making process underpinning the court's work. This concept reveals how (groups of) actors construct reality through communication processes and out of ambiguity, "when a flow of organisational circumstances is turned into words and salient categories" (Weick et al. 2005: 409).

\subsubsection{Methodology}

The aim of the present study is to account for formal and substantial cooperation between groups of professionals involved in the decision-making of the SIC, focussing on prisons and courts. The in-depth field study took place in two French-speaking SIC and in two prisons. In total, 64 semi-structured interviews were conducted, in the courts $(n=23)$, at the central administration $(n=20)$, and in prison $(n=21)$. Extensive notes were taken while observing judges, prison governors and clerks at work $(n=6)$, and during hearings $(n=8)$. Finally, we also analysed case files before the hearing $(n=8)$. Based on an inductive approach, the qualitative data collected were progressively used to refine and update the assumptions and findings, allowing us to highlight the importance of cooperation in the decision-making process of the court.

\subsection{The Legal Coordination by the 2006 Act}

In Belgium, following the Dutroux Affair in 1996 (Walgrave and Varone 2008), the conditions of early release are enacted in the External Legal Position Act of 2006. As a consequence, SIC (Sentence Implementation Courts) have replaced the former "Parole Commissions" and are responsible for granting conditional release (Bauwens et al. 2012), electronic monitoring (Beyens and Roosen 2013), semi-detention, and provisional release in view of expulsion or extradition (De Ridder et al. 2012) to prisoners serving a sentence of more than three years. However, since the implementation of the 2006 Act is not yet fully achieved the Minister of Justice, via the DMD (Detention Management Department at the Prison Central Administration, or "Direction Gestion de la Détention"-_DGD), remains responsible for granting provisional release to prisoners serving a sentence of up to three years. 
The judicialisation of early release is not complete. It is still a hybrid system where judicial and administrative decisions coexist. Indeed, the 2006 Act states that the Minister of Justice, via the DMD, is responsible for granting short prison leave (such as "permission de sortie", of up to sixteen hours maximum, and "congé pénitentiaire", up to $36 \mathrm{~h}$ maximum) (articles $4-9^{3}$ ). Short prison leave is a turning point for the prisoner: it is an opportunity to reconnect with society and his/her family, but also to look for a job, a flat, some professional training and employment that can be part of his/her "reintegration plan". In this paper, we will see that DMD and SIC decisions are interdependent, with short prison leaves providing a gradual transition to early release.

Each chamber of the SIC is composed of a professional judge (the President) and two non-professional assessors, one specialised in prison matters, and the other in social reintegration. Belgian prisoners become eligible for early release between one and two thirds (for legal recidivists) of their sentence (articles 21-26). When eligible, the prisoner submits an application form to the prison clerk's office. The prison governor must provide a (positive or negative) written recommendation within the next two months. Before writing his/her recommendation, he meets with the prisoner during a conference. ${ }^{4}$ He can also mandate the PST $^{5}$ to write a psychosocial report (Snacken 2007: 199), and a justice assistant ${ }^{6}$ for social enquiries (Beyens and Scheirs 2010). The prison governor gathers these documents and sends them to the public prosecutor of the SIC, who also writes a recommendation (articles 49-51).

The three magistrates of the SIC examine the case file before the hearing. Finally, the hearing brings together the court, the prisoner and his/her lawyer, the prison governor, the public prosecutor, and, ultimately, the victim and the justice assistant (articles 52-53). According to the law, the court can grant an early release insofar as the following counter-indications are not present in the case (article 47): (1) the lack of the prisoner's reintegration plan; (2) the risk of committing new serious offences; (3) the risk of causing further distress or offence to his/her victim(s); and (4) his/her efforts to pay debts to the civil parties. One more counter-indication was added in $2013^{7}$ : the effort of the prisoner to compensate the civil parties, which is redundant when the fourth counter-indication is considered. Those counter-indications can nevertheless be balanced by the imposition of conditions, such as the obligation of having daily employment. No appeal may be issued on the substance of a judgement, but well on the legal aspects of the judgement. The Court of Cassation is then competent to decide (articles 96-97).

In their daily practice, the Presidents of the SIC organise their jurisdiction independently from each other (Anleu and Mack 2008). The division of labour between the president and the assessors is different from one chamber to another. The application of Article 59 of the 2006 Act illustrates how local variations (localisms) and autonomy prevail. This article indicates that in exceptional circumstances, the SIC may grant short prison leave within a two-month period of time, if and only if this leave constitutes a useful means to granting the early release requested. "Article 59" is a major resource for SIC, since periods of short prison leave are often blocked by the DMD. ${ }^{8}$ However, every SIC chamber manages and interprets the many "Article 59" requests addressed to them in their own way.

Various bodies are involved in the early release process: SIC, prison clerks and governors, psychosocial teams (PST), DMD, prisoners, lawyers, and the Houses of Justice. If localism prevails at the SIC level, the same statement can be made at the prison level. An attempt at standardising some procedures has been set by the Central Administration. As an example, the Ministerial Circular n¹794 of 7 February 2007 provides some detail about the meaning of counter-indications, the staff conference composition, and it gives forms and a basis for the prison internal procedure. However, prison practices are locally adapted while still meeting the law's requirements. Prison governors can decide which staff will carry out some specific 
procedures, how information will be passed on to the prisoner, how a form is completed, etc. The way procedures are translated into concrete practice depends on local contingencies (Dubois and Vrancken 2014).

Beyond legal prescription, the law sets out the role of the stakeholders in the early release procedure, without specifying every role in detail. Nor does it define the absolute meaning of the counter-indications: what should be understood by "the risk of new serious offences"? What evidence can be provided for this? And how is the court's decision passed on to the prisoner and the various actors preparing his/her file? There lies the issue of cooperation within the sentence execution process.

\subsection{Formal and Substantial Dimensions of a Collective Action Process}

The case files examined by the SIC are prepared inside prison. Prison clerks, prison governors, and the PST receive, process and exchange information through meetings and documents. We will now look closer at these groups' interdependency and at their respective key resources and functions.

\subsubsection{The Prison Clerks, Bandmasters of the Legal Procedure}

The prison clerks' office, composed of one to four clerks in charge of the SIC matter, is responsible for managing the procedure. This consists primarily of calculating the prisoner's eligibility dates ${ }^{9}$ and initiating the early release procedures, but also of assembling the case file. The case file is composed of legal documents (recommendation, requests, hearing convocations, etc.), and of judicial documents (the judgement and description of the offence by the public prosecutor; the record of short prison leaves previously granted by the DMD and the SIC). The clerks' office centralises and dispatches documents that are passed through the prisoner (his application file), the DMD (short prison leave approval or denial), the governors (written recommendation), the PST (PST file, victim record), the Houses of Justice (attestation of the conditions for an eventual reintegration), and the SIC (judgements). This is the first key facility handled by the clerks: monitoring the timescales, they centralise the communication and drive the coordination between the actors involved in the process.

In some prisons, clerks are personally informing the prisoners about the procedure, the timescale, and what they have to do. Where such information is directly communicated to the prisoner by a clerk rather than by a prison guard, the length of the procedure may be reduced, because a clerk can discern whether an application will be viable or not. This expertise is a second key facility of the clerks: acting as gatekeepers, they can be the first filter in the early release process.

It is easier to go and see the prisoner directly. (...) We can talk to them quickly, I tell them that they can apply if they are ready. Since I give the information personally, half of them are filling the application form. (aA Pprison clerk)

They also ensure the prisoner's rights are respected as the prisoner depends on them to move his/her application file forward and update it frequently, recording the various administrative and judicial decisions concerning him. In doing so, they "establish the prison as a legal entity" (Salle and Moreau de Bellaing 2010: 164).

We have to respect many deadlines, regardless of our opinion. (...) We have to execute the legal procedure and the decisions. Our role is to make it work. (aA Pprison Gclerk) 
Keeping in contact with groups both inside (prison governors, the PST, prisoners) and outside the prison (DMD, Houses of Justice, SIC) is the third key facility of the clerks. For example, they have regular contact with the court's clerks: they exchange files, hearing schedules and judgements. These three key facilities make clerks powerful: concretely enacting the procedure, the coordination between the various groups of actors depends on them, so that the files can be processed on time.

\subsubsection{The Prison Governors, Strategic Brokers}

A prison's management staff is usually composed of four to twelve governors, according to the size of the prison. The governor, who is responsible for the prisoner's detention, has to write a positive or negative recommendation for every request. To do so, they meet with the prisoner during the conference. They can also mandate the PST to provide a psychosocial report if necessary, and mandate the House of Justice to lead certain social investigations. They then base their written recommendation on the information inscribed in the documents and collected during the meeting(s) (with the prisoner, the PST, the clerk, the guards). Later in the process, during the hearing to decide whether leave or early release is granted, they orally update their recommendation, according to the evolution of the prisoner's situation.

The conference consists of a meeting between the governor and the prisoner. Usually, this is the place to discuss the prisoner's general situation, the state of the requests sent to the DMD, etc. Early release processes are not linear. The prison governor looks at the reintegration plan, he gives advice to increase the chances of success. Many governors conceive the conference as an opportunity to work on the requests and files, but also with and for the prisoner. In the following example, the governor advises a prisoner, as he knows that his case file fits with "Article 59", and that the court's magistrates could be sensitive to some arguments.

\section{A conference: Alex (I)}

Alex's request for electronic monitoring (EM) is being discussed during the conference. His lawyer is not present. The DMD had previously granted Alex a one-day prison leave that was successful. But the DMD is now refusing to grant Alex a weekend leave, blocking any conditional release application. The prison governor explains to Alex that he has to apply again for a weekend leave: "I will write a positive recommendation. But you should submit an "Article 59" [request] to the court. The main justification to be developed is that your reintegration plan is only missing a test of cohabitation at your mum's. And you have to insist on the fact that the DMD keeps refusing the weekend leave requests".

Along the preparation of the file, prison governors can give some information, explanation and advice to the prisoners about the procedure. Their knowledge of the case, inscribed in various documents, is a first key resource.

In meeting with the prisoner before and at the hearing; reading and interpreting judicial, administrative, social and psychosocial documents in order to write their recommendation; and transmitting this recommendation to the court: prison governors are experiencing interactions between various professional groups, both inside the prison and with the SIC. Their "boundary spanning" position is a second key resource, "possessed by an actor participating in several related systems of action. As a result, [they] can play the indispensable role of intermediary and interpreter between different and even contradictory logics of action" (Crozier and Friedberg 1980: 41). 
Along their career, prison governors become familiar with judicial and administrative routines, categories, expectations, and reactions that comprise the courts' jurisprudence. Their experience is a third key resource as it enables the prison to react "to the data or problems that have been previously perceived, recognised and understood by its members, who must then integrate them into the causal maps that they construct from experience and that provide them with their representations and scenarios for interpreting the world" (Friedberg 1997: 58).

Since we have no access to the Court, the governor is a relay person. After the hearing, he gives us a quick feedback of whatever has been said, so that we can have an insight on what happened. (Social worker PST)

While writing their written recommendation, prison governors have to collect and make sense of various documents produced by different professional groups (DMD, SIC, PST, Houses of Justice) using different languages, tools, and guided by different professional and institutional norms (Hutton 2006). Governors not only summarise and assemble the information out of these documents, but they also translate, compare, make sense of them, in the light of the information collected during the conference. Beyond the procedure, the governors are enacting the substantial dimension of the files, making sense of various documents, and feeding the justification of the SIC's decision downstream. In doing so, prison governors are brokering substantial knowledge on the prisoner's situation to the court and on the court's expectations to the prisoner.

\subsubsection{The Psychosocial Report, a "Boundary Object"}

The psychosocial teams are composed of 15-25 members, psychologists and social workers, who are responsible for evaluating the prisoner. They are subordinate to a double hierarchy: the local prison governor and the central psychosocial department. As previously mentioned, they are mandated by the governors to write a psychosocial report, whose content depends on what the governor has requested. ${ }^{10}$ Having no direct contact with the court, the PST can influence and in-form the final decision through his written report and via the governor who takes part in the hearing.

The PST takes part in the preparation of the prisoner's request for the DMD, and contributes to the elaboration of his/her reintegration plan. Above all, the key resource of the PST lies in the psychosocial report. It influences the governor's and the public prosecutor's recommendations and the court's decision by providing them with material (risk evaluation, criminogenesis, anamnesis, the prisoner's attitude towards the victim(s) and towards the facts, etc.). Making this material available, the psychosocial report plays a big role in the labelling process, framing the file. The document produced by the PST will be examined by the governors, the DMD, the public prosecutor and the court in order to produce their recommendation, inform their decision and justify it, although the influence of the psychosocial report can remain invisible in the SIC judgement.

Everybody knows that the PST report plays a central part in the whole process. (Prison governor)

The psychosocial report illustrates the role of "boundary objects" (Star and Griesemer 1989) in a decisionmaking process. Boundary objects pass information from one group to another: "Both plastic enough to adapt to local needs and the constraints of the several parties employing them, yet robust enough to maintain a common identity across sites. [...] They have different meanings in different social worlds, but their structure is common enough to more than one world to make them recognisable, a means of translation" (Star and Griesemer 1989: 393). Because they do not require any consensus, the different groups of actors using boundary objects can make sense of them in and according to their local context of action. The substantial 
information the psychosocial report carries is neither received nor perceived in the same way by every stakeholder. Every professional uses, translates and makes sense of the report in his/her own way, according to his own professional practices, language, tools and constraints. In that respect, the psychosocial report is "plastic". But the report is also "robust", as it is part of a routinised process: if the 2006 Act barely mentions the PST, we can observe that both the DMD and the court request it in the files, and that SIC will be reluctant to make a decision if the report is not included. The psychosocial report is a boundary object, "revealing point of exchange between two professional groups working within the criminal justice system." (Halliday et al. 2009: 407).

This section depicted how the clerks, the prison governors and the PST took part in the incremental production of prisoners' case files. From a formal point of view, they are collecting information, inscribing it in documents, receiving these documents, making sense of them, and moving them forward. From a substantial point of view, these professionals are progressively labelling both the prisoner and his case file. In the following section, we will consider this substantial dimension as a collective process of "sensemaking".

\subsection{A Collective Process of "Sensemaking"}

Taking place at the end of the early release process, every hearing is partly determined by the coordination of the procedure by the clerks, the (sometimes strategic) mediations by the governors, the "boundary object" produced by the PST, and the reading of the file by the SIC members (public prosecutor and magistrates). Three judges are responsible for making the decision, in the light of the legal counter-indications already mentioned. Partly due to the nature of these counter-indications, their judgement is based on common sense (Thévenot 1992), discussion and deliberation (Elster 1998), rather than on general rules syllogistically applied to specific cases (Beccaria 2006). They then focus progressively on the elements to be worked on by the prisoner. The judgement is written after the hearing by one of these magistrates justifying their decision with, among other things, the material included in the psychosocial report and the governors' recommendation. When the decision is negative, the justification is addressed to every stakeholder, indicating how to improve the prisoner's file for a future request.

The hearing is the place for discussing and updating the reintegration plan and the recommendations that the public prosecutor and the governor may have been writing weeks or months earlier.

\section{A hearing: Alex (II)}

Only a few days after his conference by prison governor I, Alex's hearing takes place in the absence of both his lawyer and prison governor I, the latter being represented by one of his colleagues, prison governor II. As advised by prison governor I, Alex asks the court to grant him a weekend leave under "Article 59", in order to try out the living arrangement with his mother. Alex relays the arguments that governor I has told him: the DMD keeps refusing the granting of the weekend leave, and his reintegration plan is ready but still misses the test of cohabitation. As an answer, the court president underlines that the prison governor's written recommendation on a weekend leave was negative. Alex explains that at the conference prison governor I had promised to write him a positive recommendation for his next request. Prison governor II, who is attending the hearing, says that (s)he is not aware of this. The magistrates have received the reintegration plan, the written recommendation, and the psychosocial report. But they are missing some crucial information to grant a weekend leave via Article 59: the positive recommendation. According to Alex, this positive recommendation has not yet been added to the file. After the hearing, the 
information is checked and the weekend leave can be granted via the use of Article 59.

The hearing reveals the importance of cooperation between stakeholders. Communication is a major element of cooperation within the prison and within the court as much as between both these entities. Because of their broker position, the communication process strongly depends on the prison governors, as illustrated by Alex's case. The sharing of information between colleagues (prison governors in this case) is another decisive aspect of the collective action process, which also relies on meetings and documents to make coherent sense.

Despite the fact that the SIC depends on all the other professional groups involved in the process, it has some autonomy to make decisions. A failure in the formal dimension of the collective action chain upstream does not automatically involve a negative decision downstream. Judges have been developing their own strategies to react quickly when a missing document prevents them from granting an early release (using the fax, going to the clerks' office). Sometimes, if the magistrates realise at the hearing that the prisoner is not eligible for a conditional release, or that the file does not meet the required criteria (the lack of a reintegration plan for example), they then indicate in their decision the required time needed before a new request can be made. The court also handles the substantial dimension of the process when contradictory information or miscommunication between the prison governors occurs, as in Alex's case. If their judgement partly relies on the "translation" of various documents by the PST and prison governors, they still can read the original documents composing the case file.

Moreover, the hearing reveals how the prisoner's file has been progressively framed and labelled.

\section{From the case file to the hearing(s): labelling Charly}

Charly has a heavy criminal and prison background. Having served many sentences, he was previously granted two conditional releases, which were later revoked. He has been imprisoned since 1995; his sentence (for murder, robbery and drugs offences) will expire in 2023. Since 2007, Charly has been heard ten times by the SIC. His case file mentions two PST reports, wherein five other reports are also mentioned. After a few rejections of his requests, the court asked for a psychiatric report in 2010. In 2011, the court granted Charly three one-day leaves, using Article 59. Although eligible for short leaves since 2002, none had been granted to Charly by the DMD. Thanks to the short leave granted by the court, Charly has been setting up a reintegration plan. The SIC granted him a semi-detention measure in September 2011, then electronic monitoring in March 2012. On two subsequent occasions, the court refused to grant him a conditional release, as he did not have a stable job. By May 2014, and his 10th hearing, Charly has found a flat and professional training. The court granted him a conditional release, after he had been subject to electronic monitoring for more than two years.

Charly's case file provides traces from the multiple conferences, hearings, decisions, and from the work carried out by the PST. All these documents indicate that Charly's release consisted of a long process of requests, refusals and adjustments leading to new requests, refusals, etc. The psychosocial team first mentioned that more time was needed to make an evaluation; then they and the governor recommended that Charly should go through the early release options progressively; the DGD refused every leave request; the court required a psychiatric report, before using the "Article 59" strategy.

Charly's case shows how "sensemaking" is distributed through multiple actions along the processing of the 
file (Weick et al. 2005). The "labelling and categorising" operated by professionals is progressively inscribed in documents and marked by the work already done upstream. This work mainly consists of qualifications both about the prisoner (his/her psychological state, his/her behaviour in prison, his/her reintegration plan, etc.) and from the professionals (the difficulties encountered, their concerns, recommendations, advice, expertise, etc.). Documents are the recipients of a "labelling" process, where every written contribution must be understandable by every stakeholder. In such a long process, the file is recomposed throughout the elaboration of the reintegration plan and the evolution of the prisoner: some steps in Charly's process are omitted when they are considered as meaningless regarding his actual situation. "These changes through time progressively reveal that a seemingly correct action 'back then' is becoming an incorrect action "now"' (Weick et al. 2005: 413).

\subsection{Conclusion}

A legal decision needs some justification. If the final decision lies in the judgement of the SIC, this decision is emerging all along the construction of the file. Just like in a criminal court, it "depends on the ability of the criminal process to communicate expectations and cues which guide judges in answering the question 'what type of case is this?"' (Tata 1997: 413).

The hearing and the files reveal how "sensemaking" is a nonlinear and collective process: "In sensemaking, action and talk are treated as cycles rather than as a linear sequence. Talk occurs both early and late, as does action, and either one can be designated as the 'starting point to the destination'" (Weick et al. 2005: 412). The visible dimension of this process lies in various documents; its invisible dimension leads to the hearings, where decisions are to be taken. Such a collective decision-making process is both procedural (progressive trajectory of the prisoner's request and file, according the deadlines and requirements) and substantial (incremental translation of information into documents, such as the psychosocial report, the governor's and public prosecutor's recommendation, the social enquiry, the previous decisions of the DMD and SIC). Charly's case underlines the cyclical aspect of "sensemaking". Every stage, meeting and document, including the hearings, implies the framing of the case. The qualification follows and is adapted to the evolution of the prisoner, his mental state and his reinsertion plan.

Coordination as prescribed by the law, and documents as material, are necessary but not sufficient to concretely enact the early release process. The different groups of actors need to share some common understanding of the counter-indications. The meaning of "a lack of social reintegration", or of the "risk of committing new serious offences", will vary according to the case file they have to deal with, but also according to the request and to the prisoner. This means that the various stakeholders need some flexibility in their way of working. In Alex's case, the lack of communication between the prison governors did not constitute a definitive obstacle for the "Article 59" strategy conceived by the first governor to be performed by the SIC. Alex's file, the preparation of the reintegration plan, the rejection of a previous request by the DMD, and his cooperation with the PST; all these factors are contributing to the collective decision finally made by the court. These elements are brought together and given sense by the professionals involved in the process. It is through meetings and documents that these elements are elaborated and discussed with the prisoner, then communicated to the court, where they will be (partly) validated or not.

Meetings and documents compose the collective action process conceived as "organisational sensemaking". The decision of the SIC is the output of a retrospective process (Weick et al. 2005:411) woven by actors who are memorising some effective solutions and adjusting their actions to the available clues. In Alex's case, the back and forth movement of the documents and of the oral communications incrementally allowed 
his case to be categorised according to previous experiences and recollections of other prisoners. But "sensemaking" is also retrospective because it always consists of interpreting, bracketing and labelling already existing facts, documents, information: "A mistake follows an act. It identifies the character of an act in its aftermath. It names it. An act, however, is not mistaken; it becomes mistaken" (Paget 1988: 56, quoted by Weick et al. $2005: 412$ ).

\section{References}

Anleu, S. R., \& Mack, K. (2008). The professionalization of Australian magistrates: Autonomy, credentials and prestige. Journal of Sociology, 44(2), 185-203.

Bauwens, A., Robert, L., \& Snacken, S. (2012). Conditional release in Belgium: how reforms have impacted recall. European journal of probation, 4(1), 19-33.

Beccaria, C. (2006). An Essay on Crimes and Punishments (242 p.). The Lawbook Exchange Ltd.

Beernaert, M.-A., \& Vandermeersch, D. (2008). Le tribunal de l'application des peines et le statut externe des condamnés à des peines privatives de liberté de plus de trois ans (162 p.). Kluwer.

Beyens, K., \& Roosen, M. (2013). Electronic Monitoring in Belgium: A Penological Analysis of Current and Future Orientations. European Journal of Probation, 5(3), 56-70.

Beyens, K., \& Scheirs, V. (2010). Encounters of a different kind Social enquiry and sentencing in Belgium. Punishment \& Society, 12(3), 309-328.

Crozier, M., \& Friedberg, E. (1980). Actors and Systems: The Politics of Collective Action (341 p.). The University of Chicago Press.

De Ridder, S. D., Beyens, K., \& Snacken, S. (2012). Does Reintegration Need REHAB? Early Release Procedures for Prisoners without a Legal Permit of Residence in Belgium. European Journal of Probation, $4(3), 21-37$.

Dubois, C., \& Vrancken, D. (2014). Restorative detention or 'work on self'? Two accounts of a Belgian prison policy. Ethnography.

Elster, J. (ed). (1998). Deliberative Democracy (Vol. 1) (294 p.). Cambridge University Press.

Freeman, R. (2006). The Work the Document Does: Research, Policy, and Equity in Health. Journal of Health Politics. Policy and Law, 31(1), 51-70.

Friedberg, E. (1997). Local Orders: Dynamics of Organized Action (330 p.). Jai Press Inc.

Garapon, A. (2001). Bien juger : Essai sur le rituel judiciaire (352 p.). Odile Jacob.

Halliday, S., Burns, N., Hutton, N., Mcneill, F., \& Tata, C. (2009). Street-Level Bureaucracy, Interprofessional Relations, and Coping Mechanisms: A Study of Criminal Justice Social Workers in the 
Sentencing Process. Law \& Policy, 31(4), 405-428.

Hutton, N. (2006). Sentencing as a social practice. In S. Armstrong \& L. McAra (Eds.), Perspectives on Punishment (pp. 155-174). Oxford University Press.

Mine, B., \& Robert, L. (2014). Le processus décisionnel relatif aux permissions de sortie et aux congés pénitentiaires. Revue de droit pénal et de criminologie, 3, 267-287.

Salle, G., \& Moreau de Bellaing, C. (2010). Les grincements d'un rouage de l'État. Terrains \& travaux, ${ }^{\circ}$ $17(1), 163-180$.

Snacken, S. (2007). Penal Policy and Practice in Belgium. Crime and Justice, 36(1), 127-215.

Star, S. L., \& Griesemer, J. R. (1989). Institutional Ecology, 'Translations' and Boundary Objects: Amateurs and Professionals in Berkeley's Museum of Vertebrate Zoology, 1907-39. Social Studies of Science, 19(3), 387-420.

Tata, C. (1997). Conceptions and Representations of the Sentencing Decision Process. Journal of Law and Society, 24(3), 395-420.

Thévenot, L. (1992). Jugements ordinaires et jugement de droit. Annales. Économies, Sociétés, Civilisations, 47(6), 1279-1299.

Walgrave, S., \& Varone, F. (2008). Punctuated Equilibrium and Agenda-Setting: Bringing Parties Back in: Policy Change after the Dutroux Crisis in Belgium. Governance, 21(3), 365-395.

Weick, K. E., Sutcliffe, K. M., \& Obstfeld, D. (2005). Organizing and the Process of Sensemaking. Organization Science, 16(4), 409-421.

1 May 17 2006, "External legal position of persons convicted to deprivation of freedom and the rights accorded to the victim in the framework of the modalities of the execution of sentence", Moniteur Belge 15.06.2006, p. 30455.

2 The laws of 5th and 18th March 1998 established these commissions.

The article of the law in this section refers to the Law of May 17 2006, "External legal position of persons convicted to deprivation of freedom and the rights accorded to the victim in the framework of the modalities of the execution of sentence", Moniteur Belge 15.06.2006, p. 30455.

4 The conference consists of the legally required meeting between the prisoner applying for early release and the prison governor.

5 The Psychosocial Teams are part of the Prison Service. They are responsible for diagnosis and "pretherapeutic actions, including motivating prisoners to accept treatment upon early release" (Snacken 2007 : 170).

6

The Houses of Justice were introduced in 1998 in every Belgian judicial district, essentially to coordinate probation, early and conditional release supervision, victim support, and mediation. The justice assistants fulfil these tasks.

7 Law December 15, 2013 “diverse disposition in order to improve the victim' status in the framework of implementation of sentences", Moniteur Belge 19.12.2013, p. 99993.

${ }^{8}$ Quantitative study of DMD decision-making showed that the decisions made were positive for $55.8 \%$ of requests that had received a positive recommendation from the prison governor (Mine and Robert 2014:285).

9 Calculating the dates of eligibility is a complex exercise (Beernaert and Vandermeersch $2008: 75$ ).

10 The request might concern the prisoner's familial and personal situation, a comparative description of the facts as viewed by the public prosecutor and by the prisoner, the prisoner's attitude towards the facts and the victims, his behaviour during his detention, some investigation about his personality, his reintegration plan, his social situation, and most of all, the risk of re-offending. The reports are very different (from 1-50 pages), depending on their author, the offence, the offender, the sentence, etc. 